\title{
Afterword Soviet Jews in World War II: Experience, Perception and Interpretation ${ }^{1}$
}

\author{
Zvi Gitelman
}

Nearly seventy years after the Holocaust ended, we continue to be perplexed, horrified, pained, worried and fascinated by it. Unfortunately, genocidesthe purposive killing of peoples because they are peoples-have continued to this day. However, neither the events in Rwanda-Burundi, nor the Balkans, nor Cambodia, nor Darfur occupy as much of the world's attention as does the Holocaust, perhaps for three reasons: first, the scale of the Holocaust is unparalleled. Second, its purposive, deliberate and industrialized design sets it apart from more spontaneous outbreaks of ethnic or racial rage and destruction. This was not a localized war between Hutus and Tutsis; Serbs, Croats, and Muslims; or one group of Cambodians or Sudanese against another. Third, it was designed and largely perpetrated by a nation that was considered among the most civilized in the world. The Germans were the main culprits, but significant numbers of Dutchmen, Belgians, Frenchmen, Romanians, Hungarians, Austrians, Lithuanians, Estonians, Latvians, Ukrainians, and others participated in the crimes collectively known as the Holocaust. It is the Germans who have been the most willing to confront themselves and their crimes. Some of the others did so only long after the events, and still others maintain to this day that it was not their hands that spilled blood. ${ }^{2}$ In the face of undeniable facts and evidence, some of which continue to be literally unearthed, explanations have been sought for denial or silence. In Eastern Europe, the most common rationale is that the Jews had betrayed the states in which they lived by collaborating with the Soviet Communists. Maybe not all Jews were Communists, it is said, but we can understand why people oppressed by Stalinist totalitarianism believed they 
were. Debates over culpability, responsibility, justice and retribution will undoubtedly go on for years. These are only in part debates about facts; mostly they are arguments from different perspectives.

About half a century elapsed before scholars could study the Holocaust in the Soviet Union and related subjects such as Soviet policies during the war, evacuation of civilians to the Soviet rear and the representation of the varied experiences of the war in Soviet and post-Soviet literature and the arts. As this volume makes clear, during and after the war the Soviet government, Soviet peoples and even Soviet Jews saw the annihilation of the Jews in a very different way than it has been perceived in the West and Israel, and they continue to do so. For most non-Soviet Jews, the crux of the events is the calculated murder of a third of the worldwide Jewish people. For most Jews from or in the Former Soviet Union (FSU), what should be emphasized is the heroic struggle of Soviet Jews against the Fascists. Of course, for non-Jews in the FSU the story is that of the sacrifice and heroism of the Soviet people, and, as Stalin put it in his toast in the Kremlin on May 24, 1945, above all of the Russian people, whom he called "the most outstanding nation of all the nations who belong to the Soviet Union."

The conference from which this book derives had three goals: first, to present new information; second, to demonstrate how and why Soviet Jews and non-Jews have different perspectives on the Holocaust than those dominant in the West; and, third, to explore some contemporary issues in former Soviet territories that emanate from the Holocaust. We wanted to open up a subject that is largely unknown in the English-speaking world, that is, the role of Soviet Jews as combatants in the Soviet forces that bore the brunt of the fighting against the Nazis. Most chapters in this book have as their evidentiary base largely unknown materials-documents, literature and oral history. This book should raise awareness of the subject, especially among English speakers; increase our understanding of Soviet Jewry during WWII, even while complicating it; and stimulate more research and greater understanding.

\section{The Setting}

About half of all the victims of the Holocaust were Soviet citizens at the time they were killed. In the USSR, perhaps 2.7 million Jews were killed, constituting 55 percent of the entire Jewish population of the country in June 1941, as 
Oleg Budnitskii points out in his chapter. The reason we know less about the Holocaust in the USSR than we know about how it occurred in other countries is that Soviet authorities-who controlled all mass media, publications, and curricula-while never denying that the Holocaust took place, chose not to have it commemorated, considered, or written about. Moreover, since the collapse of the USSR at the end of 1991, most of the original research done about the Holocaust in the former Soviet heartland has been published in Russian and Hebrew, closing it off to many.

What differentiates the Shoah in the Soviet Union from the deliberate and systematic murder of Jews in other places?

While the perpetrators of the Holocaust had the same general goal in all the areas they conquered, in the Soviet Union they declared the specific aim of eradicating Bolshevism as well as the Jews, which they equated. There was a prominent political dimension as well as a racial one to the attack on the Soviet Union. Second, the scale of human and material loss was enormous. The Soviet Union lost about 26-27 million of its citizens during the war, 8-9 million of them in combat. That country saw by far the most ferocious combat over a longer period of time than any other place in Europe, and perhaps in Asia. Losses on both sides were enormous. Of the over five million German soldiers who died in World War II, 52 percent $(2,743,000)$ died on the Eastern Front, and 23 percent $(1,230,000)$ in the final battles in Germany, in which the Red Army played a large role. ${ }^{3}$ The Soviet Union played " $a$, if not the, decisive role in defeating Nazi Germany."

Soviet losses have been reported differently over time, both for political reasons and because the information has become available slowly. Stalin announced in 1945 that 7 million had been killed, but a more recent estimate is that about 26 million Soviet citizens died during World War II, of whom about $8,668,400$ were in the military. The Soviet Union suffered the third highest proportion of civilian deaths-12 percent of its population-if Soviet calculations are accurate. ${ }^{5}$

There were also significant losses in the Soviet Union by Germany's Romanian, Hungarian, Italian and other allies. Given the scale and intensity of the fighting, one could expect a great deal of what is euphemistically referred to as "collateral damage" in the USSR, including human and material losses. That was compounded by the Nazis' deliberate destruction of infrastructure and people, something they did not do in Western Europe. For example, if some villagers were suspected of contact with partisans, the whole 
village might be burned down, sometimes with all its inhabitants. There were many Lidices, many Oradours-sur-glane. Moreover, before World War II in the eastern parts of Europe brutality was the common experience of millions. There were revolutions in 1905 and 1917, the 1914-1918 world war, and a brutal civil war in Russia and Poland in 1918-21, which was largely face-toface, all of which resulted in millions of civilian casualties. In 1928, Joseph Stalin launched the campaign to "collectivize" agriculture that resulted in the deaths of probably eight million peasants. The massive politically motivated purges between 1934 and 1940 cost tens of millions their lives, and other tens of millions their freedom. In territories annexed by the USSR in 193940-the Baltic states, eastern Poland and Bessarabia-Bukovina taken from Romania-there had been dictatorial and antisemitic regimes in power and much grass-roots anti-Semitism. These states barely tolerated and largely oppressed their ethnic and religious minorities, none more so than the Jews. Resentments and hatreds were simmering and needed only the sparks of war to burst into full flame, leading to multilateral ethnic wars that took place within the Second World War. Thus, Finns and Russians, Balts and Russians, Poles and Ukrainians, Romanians and Russians all fought each other in the context of the Second World War. Extreme and pervasive violence, often based on ethnic and religious rivalries, suffused the western peripheries of the USSR in a manner unparalleled in western Europe.

\section{The Perpetrators' Perspective}

The Nazis singled out Bolshevism as the most pernicious political doctrine and system. Already in 1930, Adolf Hitler described the Soviet regime as "on a Slavic-Tatar body is set a Jewish head."' General Von Manstein wrote that "The Jewish-Bolshevist system must be exterminated once and for all. The soldier must appreciate the necessity of harsh punishment of Jewry, the spiritual bearer of Bolshevist terror." ${ }^{\text {R }}$ Russians, Belorussians and Ukrainians were regarded as scum, and it took less provocation to kill them than it did other Slavs. The Nazis flirted with nationalist Ukrainians oppressed under Polish rule who saw the Nazis as potential liberators and sponsors of Ukrainian independence, but fairly quickly the Nazis decided to forego the strategic opportunity to make an alliance that might have served them decisively.

The Holocaust in the USSR was also facilitated by the attitudes of the German troops and their allies. The "Eastern Front" was rightly regarded 
as a much tougher posting than anywhere else. In addition, German forces had been persuaded that they were not fighting against civilized people, such as the Dutch, French or Norwegians, but against primitive beasts. They also knew that surrender was a terrible option. The combination of resentment and fear at being in the East and the conviction that the lives they were taking were not worth living may have led the Eastern Front troops to greater acts of vengeance, brutality, and sheer cruelty than anywhere else in the war.

\section{Perspectives of Collaborators}

Collaboration with the Nazis was also different in the East from the West. In the West, most collaborators were either ideologues persuaded of Nazi doctrines or opportunists who saw collaboration as a means of survival and even making life reasonably comfortable for themselves. In the East, motivations were more complicated. Some saw the Nazis as liberators who afforded them the opportunity to take revenge on Soviet oppressors, whom they identified with the Jews. Many reasoned that "my enemy's enemy is my friend:" Baltic peoples who had enjoyed independence for only two decades before the Soviets annexed their countries; some Ukrainians who saw the Nazis as liberators from the yokes of Communism and Polish rule; and other Soviet citizens who bore deep resentments against a Bolshevik regime that had taken their property, their churches and the lives of their relatives. They had little compunction about taking Jewish lives (this was true even after the war) because they believed in the Zydokomuna-the "Kike-Commie Conspiracy" - and had seen Jews being murdered with impunity twenty years earlier during the Russian Civil War. Many were engaged in brutal wars, settling real or imagined scores between them and their neighbors. Life was highly uncertain and devalued. Killing was not a rare exception, nor was betrayal. Desperate people thought and behaved in ways that would have been unacceptable in "normal" times.

Wartime collaboration remains a fraught issue in post-Communist states, as it was for decades in France, Belgium and other countries. Whether to bring up the issue, how to address it, and whom it should affect are still debated in and beyond the region. The issue remains a sticking point between world Jewry and the State of Israel, on one hand, and several post-Communist states, on the other. 


\section{The Jewish Victims}

The situation of Soviet Jews on the eve of the war was radically different from those elsewhere in Eastern Europe. Soviet Jews had no communal institutions, which might have provided some support in the initial phases of the Holocaust, because the Soviet government had dissolved them in the 1920s. They had no means of self-defense, no authoritative bodies or figures to turn to for succor or advice. Most had been shielded from knowledge of Nazi radical antisemitism by the curtain drawn over it by the Soviet media, though some got word in 1939-40 of what was happening to Polish Jews. ${ }^{8}$ As several authors in this volume point out, many Soviet Jews remembered the Germans of World War One as decent, civilized people with no particular animus against Jews. Some in Ukraine began to feel at the outbreak of the war that they were more endangered by their Ukrainian neighbors than by the Nazis. Authors Estraikh and Zeltser show that many younger Jews had ceased to think of themselves as Jews, and firmly believed they were part of a new internationalist society where invidious distinctions based on ethnicity would no longer be made.

What set Soviet Jews apart from those of other conquered countries was that as individuals, not as a self-consciously Jewish group, hundreds of thousands were able to combat the Nazis and their allies. There were about half a million Jews in the Soviet military, the same number as in the American armed forces, except that in the Soviet Union about 140-180,000 of them were killed (30-36\% casualty rate) whereas among the US personnel about 8,000 died out of a total number of war deaths of 480-500,000 (2\%). We can deliberate over whether we would want to classify this as "Jewish resistance." Whatever we may think, my own impression from oral interviews with Soviet Jewish war veterans is that the great fought as patriotic Soviet citizens, not primarily as Jews. They fought to save themselves and their families, as all soldiers do, but also for their homeland, the USSR. They were not driven to save the Jewish people per se, and many say they were unaware of German intentions and actions when they first entered the service, and some, for quite some time after. Oleg Budnitskii arrives at the same judgment, though Mordechai Altshuler argues that the Jewish consciousness of many combatants was raised by their experiences. Both base their chapters on letters, oral histories and diaries. Of course, we do not know how many Jews hid their Jewishness during and after the war because what they saw convinced them 
there was nothing to be gained by being Jewish. That is, for some the war experience may have extinguished or diminished Jewish consciousness.

Perhaps we may think of the actions of Soviet Jewish combatants as resistance to the Nazi invasion by Soviet citizens who were Jews, rather than "Jewish resistance" to the Nazi Holocaust. Soviet Jewish partisans, on the other hand, were, for the most part, people who had escaped ghettoes and were fully aware of Nazi anti-Jewish atrocities. Their motivations for fighting were self-preservation, of course, sabotaging the general German war effort, a goal they shared with all Soviet combatants, but also explicitly saving as many Jews as possible. ${ }^{9}$

There was another important difference in perspective between two types of Jewish combatants, the so-called zapadniki, or freshly-baked Soviet citizens from the areas annexed in 1939-40, and the "real" Soviet Jews who had grown up under the new regime. The zapadniki had been Soviet citizens for two years, at most, when the Germans invaded their new country. Some had been Communists or Soviet sympathizers before they became Soviet citizens, and were probably as patriotic as Jews from the Soviet heartland. But the great majority had been Zionists, Bundists, Orthodox Jews, and those with no affiliation; they were not enthusiastic Soviet citizens. On the other hand, they had seen some Nazi atrocities first hand, and were strongly motivated to fight against them. Arkady Zeltser points out in his chapter that the Soviet Yiddish newspaper, Eynikayt, "stressed that the Jews were fighting both for the whole Soviet homeland and for themselves ... as [David] Bergelson put it, 'Far zayn foterland un zayn Yidishn folk."' Eynikayt's mission was to rally foreign Jewish support for the Soviet war effort and the Yidishn folk idea was clearly designed for that purpose. In reality, it seems to me, generally speaking, the long-time Soviet Jews fought for zayer foterland and the zapadniki, farn Yidishn folk. Of course, there were zapadniki who expressed Soviet patriotism, and Soviet Jews who saw themselves as fighting for the Jewish people and the Soviet homeland.

\section{The Soviet Government and the Holocaust}

An issue that should be investigated further is what Soviet authorities knew about the Holocaust, to what ends that knowledge was put, and to which publics, if any, it was disseminated. We have to deduce Soviet policy from Soviet actions since no one has yet found written Soviet policy directives that 
would instruct people on how to deal with the mass murder of Jews on Soviet territory. The fate of many depended on snap decisions made by local officials who had no guidance from higher echelons. But by examining materials from Soviet archives, accessible at the US Holocaust Memorial Museum, the Yad Vashem archives, and elsewhere, and Soviet newspapers and literature of the time, we should be able to at least infer the calculus of Soviet policy toward the Shoah during the war itself. ${ }^{10}$ Zeltser's and Joshua Rubenstein's chapters demonstrate the nuances and subtleties of that policy.

Three cautionary notes must be struck: 1) policy calculations are likely to have shifted over the course of the war, especially as the situation changed from catastrophic defeat to costly victory; 2 ) especially in the chaotic conditions of wartime, central controls may sometimes have been non-existent or ineffective, and so local authorities may have had more discretion than we know; 3 ) it is difficult and risky to impute motivation.

When considering Soviet policies toward the murder of their Jewish citizens, it is instructive to examine what the British and American governments, then fighting the Nazis, knew about the Shoah and what they did with that knowledge. ${ }^{11}$ The British and American governments were very reluctant to publicize the atrocities they knew were occurring "in the East," especially in the early years of the war. Richard Breitman writes, "The American government was interested in broadcasting 'atrocity reports' only if they helped to mobilize the public and the outside world to win the war. Some allied officials thought that coverage of the Jewish plight hampered psychological warfare. Foreign Jews were not among the most popular groups in the United States, or, for that matter, in other parts of the world. Nazi ... propaganda ... [was] charging daily that the Allies were fighting this war only on behalf of Jews, and the American government did not want to seem to support this charge any more than Britain did."12 Breitman concludes that the British, whose code-cracking operations gave them a great deal of information on the annihilation of the Jews even early in the war, "kept this irrefutable evidence secret" and "many State Department officials chose not to believe or to act on what evidence they had." ${ }^{13}$

Was Soviet policy any different? ${ }^{14}$ Not very. My tentative hypothesis, based on research in progress, is that Soviet authorities uncovered a great deal of painfully detailed material about the Holocaust, especially after they liberated areas in which it had been perpetrated, but that they used the material very selectively. ${ }^{15}$ They were intent on documenting German plunder of 
property, murder of Soviet POWs and of Soviet Jews as special categories, and the enslavement and deportation of Soviet citizens of many nationalities. The effort made to collect this material was likely aimed at presenting a reparations bill to the Germans after the war, and demonstrating to their allies that they had paid the greatest price for victory and therefore deserved the most compensation. But the question remains why they singled out Jews as particular victims. Perhaps they thought this would resonate with their allies, since the latter had evinced special concern for the Jews in January 1942.

The Jewish fate was not usually singled out in the media, though it was also not ignored. The press reported murders of Soviet Jews and, perhaps more often, of Jews in other countries. When extermination camps such as Auschwitz, Majdanek and Sobibor were liberated, the very high proportions of Jewish victims was not brought to light. Sometimes, published reports seem to have been deliberately ignored the ethnicity of Nazi victims.

\section{Perspectives and Usable Pasts}

Yesterday's events are often interpreted differently by those interested in them, turning them into issues of today. Even the names given to the same war differ: Is it World War II or the Great Patriotic Fatherland War; the Israeli War of Independence or the Palestinian Naqba (Catastrophe); the Yom Kippur War or the October War? ${ }^{16}$ Obviously, how one stands on a war in retrospect depends on where you sit at present.

Second, the past is used for present purposes. As it was said in the Soviet Union, history is politics projected on to the past. For the Soviets, their victory in World War II, costly as it was, became the legitimating myth of the system. It justified its very existence and its policies. By the 1960s, the Revolution had passed from memory to history and lost its ability to stir the emotions. Ideology had become ritualized and stripped of its mobilizing power. The war served not only to promote a heroic image of the Soviet regime, but to excuse and forgive whatever sins Stalin, to whom the victory was attributed, may have committed. Eight million peasants were killed during the collectivization campaigns? "Perhaps, but Stalin led us to victory." The purges had terrorized the population and had decimated the most loyal Communists? "Maybe, but without Stalin we would have never won the war." Stalin's 1937 purge of the military leadership and his failure to prepare for a German invasion might have cost millions of Soviet lives? "Possibly, but Stalin planned the ultimate 
victory." Even after de-stalinization, the war served to justify the foundations of the system. Books, songs, musical compositions, films, paintings, posters, television and radio shows glorified the war and, either explicitly or by implication, the system that had not only survived it, but won it.

Some-not all-Jews, accepted that view. Tzesar Faytelson, born in Belorussia to a family that moved to Siberia so that he would not have to go to a Yiddish school, recalls that there was not much talk about the fate of Jews during the war, during which he served in the air force. He thinks that is a good thing. After all, they shared a fate with millions of other Soviet citizens. The main thing, he says, was to defend the Motherland. ${ }^{17}$ Others are aware that, even in the midst of widespread atrocities against Soviet civilians, Jews suffered a fate shared by no other nationality. One Soviet author made so bold in the heyday of glasnost' to ask, "What about the victims of Dachau, Buchenwald, Auschwitz, Sachsenhausen, and Treblinka? Is it not time to count them among those who perished in the war?"18 While he does not mention Jews specifically, the implication is clear.

For the Soviet government, the Holocaust was seen as an integral part of a larger phenomenon-the murder of civilians-whether Russians, Ukrainians, Belorussians, Gypsies, or other nationalities. It was said to be a natural consequence of racist fascism. The Holocaust, in other words, was but one of several reflexes of fascism, which was, in turn, the ultimate expression of capitalism. Thus, the roots of the Holocaust lay in capitalism, expressed in its most degenerate form. Racism was an outgrowth of capitalism.

In the West there is a vast body of literature that seeks to understand how and why the Shoah happened. There are many explanations: cultural, psychological, sociological, political and bureaucratic. I know of no book published in the USSR that sought to explain the Holocaust as sui generis. In a word, for the Soviets there was no mystery about the Holocaust, and none about German atrocities in general.

More recently an issue of competitive victimization has arisen. Not very long ago, most people preferred to be heroes and victors, rather than victims and losers. Today, it seems that many revel in the role of victims, or, more accurately, proxies for or heirs of victims. Earlier scorn for victims of prejudice and violence has been replaced in many quarters by a combination of sympathy and guilt, at least outwardly expressed, whether inwardly felt or not. Being a direct victim is a terrible thing; but claiming to be part of a victimized group may bring some rewards. In addition to sympathy, it may 
legitimize claims to compensation, preferential treatment and political and social support. Beyond concrete compensation and support, some groups resent it when their sufferings are not as widely recognized as those of others. Books have been written, for example, titled Poland's Holocaust, which is not about Polish Jews. ${ }^{19}$ Well designed surveys taken in Poland have found that "the overall tendency" among Poles "is to claim that Poles and Jews suffered just the same during the Second World War." In 1992, "32 percent [of Poles] equated the suffering of Jews with that of Poles ... 46 percent accepted the uniqueness of Jewish suffering." Ten years later, when the survey was replicated, the proportion of those equating Jewish with Polish suffering rose to 47 per cent and the proportion of those who thought the Jews had suffered more fell to 38 per cent. ${ }^{20}$

One can hardly expect an ordinary person to reflect on the fact that though millions of Poles and Jews were killed by the Nazis, the murdered Poles constituted perhaps ten percent of the Polish ethnic population, but over 90 percent of the Jews in Poland were murdered. Similarly, a Soviet or post-Soviet person, knowing that some 26-27 million of his or her compatriots died during the war, is unlikely to reflect upon the fact that Jewish losses were more than ten per cent of Soviet military and civilian losses, though Jews were only 2.5 percent of the population at the beginning of the war. It takes a certain degree of interest and sophistication to go beyond the huge numbers and appreciate that while there was suffering and death all around, it was not evenly or randomly distributed across all population groups.

Thus, we see that there can be many perspectives on the Holocaust, perhaps nowhere more so than in the Former Soviet Union. Similarly, there were many dimensions to the Shoah in the USSR. This volume explores several of them: persecution of Jews by their neighbors, and their confinement in ghettos; the activities of the Jews themselves: those who were evacuated or deported to the interior of the USSR, a unique experience in Europe; those who fought in the Soviet military; and how Jews and other have understood and represented their experiences during and after the war. The Holocaust is for many not history alone, but an issue with which we must continue to be grapple, as shown by several chapters.

We are under no illusion that this volume settles these issues. Rather, we hope it opens windows onto a variety of subjects, new perspectives, exciting possibilities, fresh ideas and, above all, greater understanding of that which, in the final analysis, has eluded human understanding for over sixty years. 


\section{Notes}

1 Much of the research informing this chapter was done while I was a Shapiro Senior Fellow at the Center for Advanced Holocaust Study, United States Holocaust Memorial Museum in 2005-06.

2 It was only in 2009 that Romania, under pressure from the United States Holocaust Memorial Museum, Eli Wiesel, and others, erected its first monument to the Holocaust.

3 On the Einsatzgruppen, see Yitzhak Arad, Shmuel Krakowski and Shmuel Spector, eds., The Einsatzgruppen Reports (New York: Holocaust Library, 1989); Helmut Krausnick and Hans-Heinrich Wilhelm, Di Truppe des Weltanschauungskrieges: Die Einsatzgruppen der Sicherheitspolizei und des SD 1938-1942 (Stuttgart: Deutsche Verlags Anstalt, 1981). I am grateful to Geoffrey Megargee of the United States Holocaust Museum for these references. He cautions that the Arad, Krakowski, and Spector book contains some poor translations.

4 Jeffrey Herf, "The Nazi Extermination Camps and the Ally to the East: Could the Red Army and Air Force Have Stopped or Slowed the Final Solution?” Kritika 4.4 (Fall 2003), 917.

5 Presumably, these figures include "natural" deaths, though what a "natural" death was under the Nazi occupation that brought disease, famine and other privations, is difficult to define. Soviet calculations are that 17.2 percent of the Polish population (including Jews and Poles), 12.7 percent of the German population, 11.5 percent of the Soviet population (which was 168,524,000 in 1939) and 10.9 of Yugoslav civilians died during the war.

6 Quoted in Alexander Dallin, German Rule in Soviet Russia, 1941-1945, $2^{\text {nd }}$ ed. (Boulder, CO: Westview, 1981), 9.

7 Quoted in Matthew Cooper, The Phantom War (London: Macdonald and James, 1979), 171-73.

8 See Mordechai Altshuler, "Hamifgash bein lokhamim yehudim ba-tsava ha-adom lashoah," Dapim 23 (2009): 1-27.

9 The categories of soldier and partisan cannot be neatly separated since some partisans were escaped POWs who were soldiers before they were partisans, and others were drafted into the Red Army after their areas had been liberated, so that they were partisans before they became soldiers.

10 I have written on the Soviet treatment of the Shoah in the post-war period in "Soviet Reactions to the Holocaust," in The Holocaust in the Soviet Union, ed. Lucjan Dobroszycki and Jeffrey Gurock (Armonk, NY: M. E. Sharpe; 1993), 3-28.

11 I am concerned with the governments, not with mass media, mass publics or Jewish organizations.

12 Richard Breitman, Official Secrets: What the Nazis Planned, What the British and Americans Knew (New York: Hill and Wang, 1998), 135-36.

Ibid., 229. 
14 The British and Americans confronted an issue that the Soviets dealt with differently because the issue presented itself in different forms. Communist refugees from the Nazis had come to the USSR in the 1930s.

15 The first systematic reports came from "Military Commissions," which collected eyewitness testimonies very soon after an area was liberated. Somewhat later, information was gathered by the "Extraordinary State Commission to Examine and Investigate German-Fascist Crimes Committed by the Invaders and Their Accomplices on Soviet Territory" (Chrezvychainaia gosudarstvennaia komissiia po ustanovleniiu i rassledovaniiu zlodeianii nemetsko-fashistskikh zakhvatchikov i ikh soobshchnikov).

16 A comprehensive discussion of how wars are remembered and what significances are attached to them is T.G. Ashplant, Graham Dawson and Michael Roper, eds. The Politics of War Memory and Commemoration (London and New York: Routledge, 2000), Part One (3-86).

17 Visual History of the Shoah, ID: 11131. The interview was conducted in Los Angeles on January 25, 1996.

18 A. M. Samsonov, Znat' i pomnit': Dialog istorika s chitatelem, 1st ed. (Moscow: Izdatel'stvo Politicheskoi Literatury, 1988), 22.

19 Tadeusz Piotrowski, Poland's Holocaust: Ethnic Strife, Collaboration with Occupying Forces and Genocide in the Second Republic, 1918-1947 (Jefferson, NC: McFarland, 1998).

20 Ireneusz Krzeminski, ed., Antysemityzm w Polsce $i$ na Ukraine, raport $z$ Badan (Warsaw, 2004), quoted in Hanna Kwiatkowska, "Antisemitism by Numbers," East European Jewish Affairs 36.1 (June 2006): 106-7. 